\title{
AZ M6-OS AUTÓPÁLYA REGIONÁLIS HATÁSÁNAK BEMUTATÁSA A DÉL-DUNÁNTÚL RÉGIÓBAN ${ }^{27}$
}

\author{
Kovács Áron \\ Tudomảnyos segédmunkatảrs, Pécsi Tudományegyetem Közgazdaságtudományi Kar, Közgazdasági-és \\ Regionális Tudományok Intézete, Pécs
}

\section{SUMMARY}

The paper presents a research conducted on the M6 motorway in the Southern Transdanubian region. The basis of the research is data of 2006-2010 provided by the Hungarian Central Statistical Office. In the analysis I compare these measures only to themselves, assuming that they are independent from the sizes and economic potential of other regions. According to the findings of the research, it can be stated, that small regions closer to the highway benefit more from their state then those which are remote from it. Despite this small regional differences cannot be clearly linked only to the M6 highway, economic differences also prevail. In order to extend regional effects of the highway combined transportation developments would be necessary (water, rail, flight), and also the connection to with other highways in the Balkan region.

Kulcsszavak: autópálya, M6, regionális hatás, Dél-Dunántúl

\section{BEVEZETÉS}

A Dél-dunántúli régió viszonylag sürü közúti hálózattal rendelkezik, de a közúti hálózat fejlesztése a vasútvonalak fenntartását háttérbe szorította. Két autópálya érinti a régiót, északról az M7-es és keletről pedig az M6-os. Mindkét autópályának kialakult a saját vonzáskörzete $^{28}$ (Ormai Zs. 2005) és így a régió központi területei hátrányba szorultak. A megyeszékhelyek elérhetöségét Pécs-Szekszárd között az M6-os ${ }^{29}$ illetve M60-as biztosítja, de már Kaposvár autópályán keresztül a másik megyeszékhelyböl nem érhető el.

Az M6-os autópályának Dunaújvárostól Szekszárdon át Bólyig érő szakaszát a 2010. március 31-én adták át. A Dél-dunántúli nyomtávnak két szakasza van: M6-os SzekszárdBóly $(49 \mathrm{~km})$ és M60-as Bóly-Pécs $(30,2 \mathrm{~km})$. A két pályarészen 87 híd, 15 útkereszteződés; 10 csomópont, 5 pihenöhely, 4 alagút és 2 mérnöki telephely van.

$\mathrm{Az}$ autópálya nem csatlakozik egy horvátországi autópályához sem, így az M6-ost nevezhetjük befejezetlenek is. ${ }^{30}$ (Erdősi F. 2006)

A régió gazdaságpolitikai zártsága, és fö kereskedelmi útvonalakból történő kiesése jelentös. A régió gazdasági kapcsolatai szinte teljesen egyirányúvá váltak, a központi térség (Budapest) felé irányultak. Ezt a célt szolgálta a közlekedési útvonalak fejlesztése (északi irány) is, amelyben a térségen belüli kapcsolatok is csak másodlagos szerepet töltöttek be. (Buday Sántha A, 2011)

\footnotetext{
${ }^{27}$ A tanulmány a TÁMOP-4.2.1. B-10/2/KONV-2010-0002, A Dél-Dunántúli régió egyetemi versenyképességének fejlesztése projekt , Dél-Dunántúl gazdasági erōforrásainak feltárása és fejlesztési lehetôségek meghatározása c. alprojekt keretében készült. Kutatás vezetője: dr. Buday-Sántha Attila.

${ }^{28} \mathrm{Az}$ autópálya térbeni fejlődési irányokat is kijelöl, urbanizációs sávok jönnek létre az út mentén, tehát az agglomerálódást is elösegíti.

${ }^{29} \mathrm{~A}$ tanulmányom csak a Dél-Dunántúlon M6 autópálya regionális hatásával foglalkozik.

${ }^{30}$ Miközben a korridorokon belül éppen a vasutak mủszaki színvonalában a legnagyobb a lemaradás, olyan autópályák is épülnek, melyek nem tartoznak a korridorokhoz.
} 


\section{1. ábra. Dél-Dunántúl közlekedéshálózata}

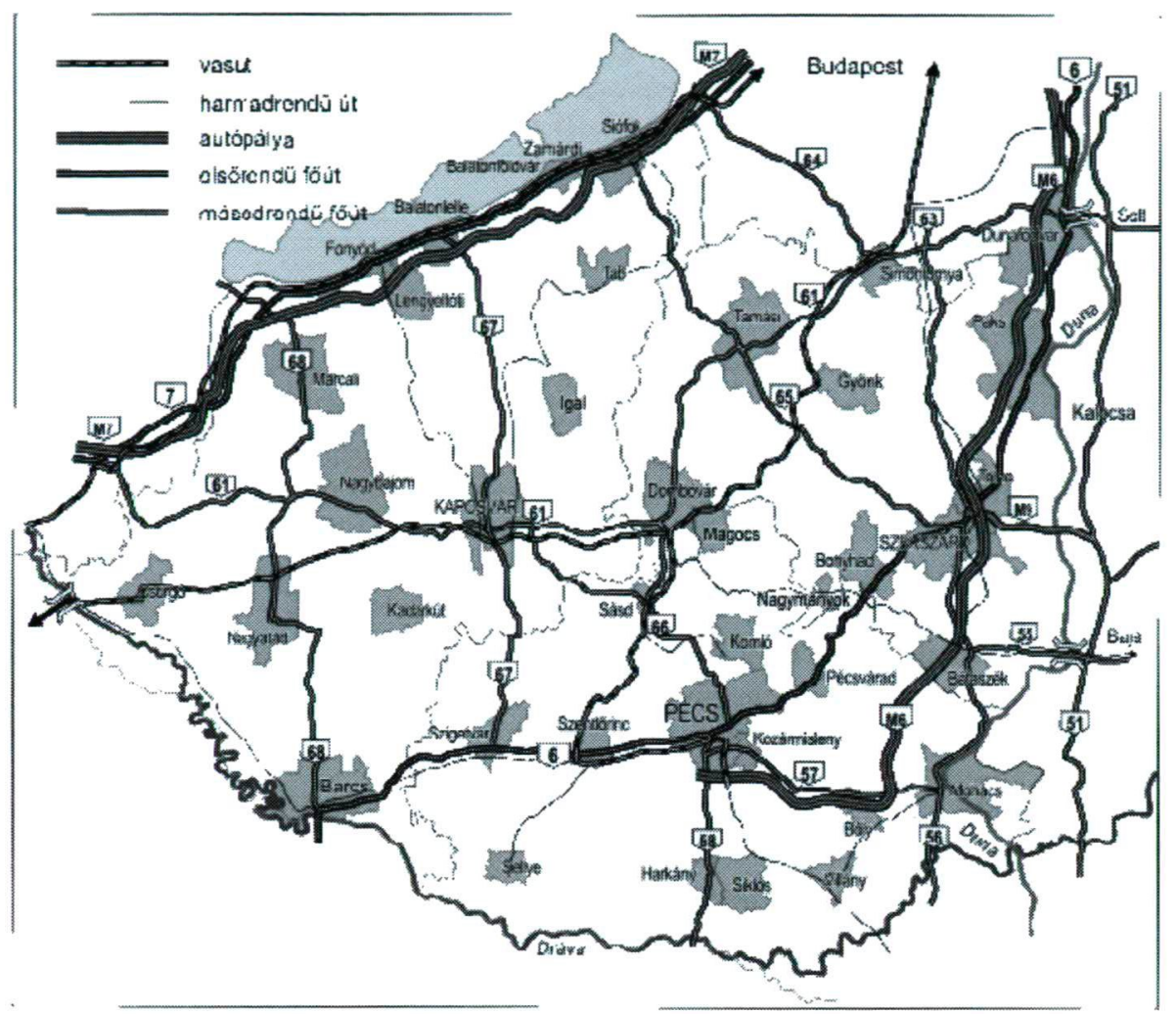

Forrás: Szerkesztette Kovács Szilárd, Dél-Dunántúli régió kutatás, TÁMOP - 4.2.1. $\mathrm{B}-10 / 2 / \mathrm{KONV}-2010-0002$ keretein belül

Dél-Dunántúl és főleg Baranya megye annyira kiesik a gazdasági fejlődés fő irányából, hogy jelentősebb nemzetközi cégek telephelynek már nem választják. Telephelyül elsősorban azok a csak kisebb cégek választják a régiót, amelyek a jelentős munkaerő kínálatra támaszkodva elsősorban térségi ellátást tűzik ki célul. Ezt bizonyítja a térség gazdaságának feltünően alacsony exporthányada is. A régió kedvezőtlen gazdaságpolitikai helyzetét jól mutatja az is, hogy a térségben nincs egyetlen nemzetközi jelentőségü logisztikai központ sem, ezért az autópálya kihasználatlanul marad. (Buday Sántha a. 2011)

\section{AZ AUTÓPÁLYA REGIONÁLIS HATÁSÁNAK ELEMZÉSE}

Az átadás óta rövid idő telt el, ezért az autópályának számszerüsíthető regionális hatása nehezen mérhető. A közlekedés hálózatok fejlesztésének egyértelmű közvetlen hatása, hogy a távolságok időben lerövidülnek. A közvetett hatás, miszerint a gazdasági, társadalmi kohéziót, már nem bizonyított. (Ormai Zs. 2005).

Az elemzéshez azokat a kistérségeket próbáltam összehasonlítani, amelyeket érinti az M6-os autópálya (Mohácsi, Pécsi, Pécsváradi, Siklósi, Paksi és Szekszárdi kistérségek) azokkal, amelyeket nem érinti, vagyis a régió belsejében elhelyezkednek el (Sásdi, Szigetvári, Dombóvári, Barcsi, Tabi és Kaposvári kistérségekkel). ${ }^{31}$ A kistérségek fejlődését a KSH által összegyüjtött megyei statisztikai adatok alapján vizsgáltam és megfigyeltem azoknak 2006 és

\footnotetext{
${ }^{31}$ Az elemzés alapját a KÁLNOKI (2005) által végzett kistérségi vizsgálata adta.
} 
2010 között bekövetkező változását. A kistérségre vonatkozó abszolút értékủ adatait használtam fel. A vizsgálat során a gazdasági adatoknak a változását a kistérségenként különkülön határoztam meg, így azok eltérő nagysága és gazdasági potenciálja az eredményeket nem befolyásolja.

\section{2. ábra. Egymással összehasonlított kistérségek elhelyezkedése a Dél-Dunántúlon}

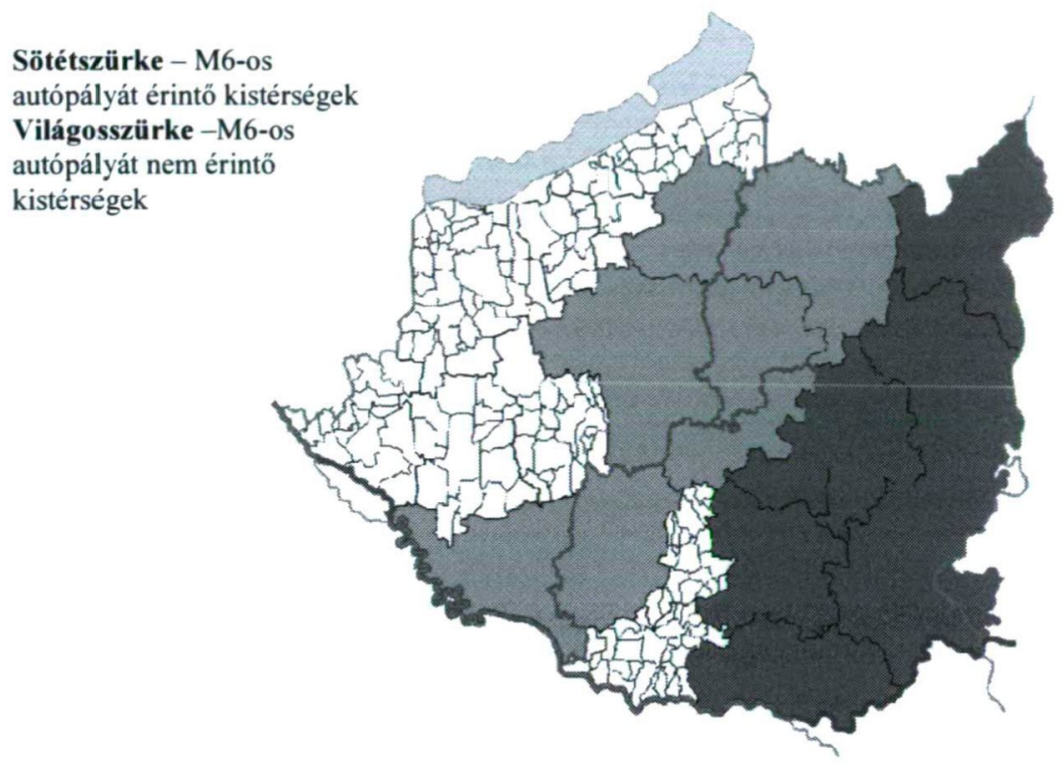

Forrás: A szerző saját szerkesztése

A megvizsgált kistérségnél, melyek az autópálya közelében vannak, azok jobb gazdasági mutatókkal rendelkeznek, mert a mezőgazdasági, ipar, építöipari, és szolgáltatói vállalatok számában nagyobb mértékủ a növekedés, mint az M6-os autópályát nem érintő kistérségeknél. A regisztrált vállalatok számának alakulása az ezzel ellentétes, mivel a régió belsejében nagyobb a növekedés, mint az autópálya közeli területeken. A gazdaság eredményességét tükrözi az egy adófizetőre jutó személyi jövedelemadó alapján képeződö jövedelem ${ }^{32}$ változása, mert M6 közelében nagyobb személyi jövedelem realizálódik, mint az autópályától távolabbi kistérségekben.

\footnotetext{
${ }^{32} \mathrm{Az}$ egy adófizetőre jutó személyi jövedelemadót képező jövedelem a belső térségekben csökkent (1,32\%-kal), az autópálya közelében átlagosan növekedett $(0,93 \%-\mathrm{kal})$.
} 
2. táblázat. Dél-Dunántúl statisztikai adatainak változása 2006-2010 között \%-ban kifejezve

\begin{tabular}{|c|c|c|c|c|c|c|c|c|c|c|c|c|c|}
\hline & & $\begin{array}{l}\text { Népesség } \\
\text { (fö) }\end{array}$ & $\begin{array}{l}\text { Egy adófizetőre } \\
\text { jutó személyi } \\
\text { jövedelemadó- } \\
\text { alapot képező } \\
\text { jövedelem }\end{array}$ & Lakásállomány & $\begin{array}{c}\text { Vezetékes } \\
\text { gázfogyasztás, } \\
\mathrm{m}^{3}\end{array}$ & $\begin{array}{l}\text { Nyugdijban, } \\
\text { nyugdijszerü } \\
\text { ellátásban } \\
\text { részesülök } \\
\text { száma }\end{array}$ & $\begin{array}{c}\text { Mezőgazdasági } \\
\text { vállalkozások } \\
\text { száma }\end{array}$ & $\begin{array}{c}\text { Ipar, épitőipari } \\
\text { vállalkozások } \\
\text { száma }\end{array}$ & $\begin{array}{c}\text { Szolgáltatói } \\
\text { vállalkozások } \\
\text { száma }\end{array}$ & $\begin{array}{c}\text { Regisztrált } \\
\text { vállalkozások } \\
\text { száma }\end{array}$ & $\begin{array}{c}\text { Kereskedelmi } \\
\text { szálláshelyek } \\
\text { száma }\end{array}$ & $\begin{array}{l}\text { Magán } \\
\text { szálláshelyek } \\
\text { száma }\end{array}$ & $\begin{array}{c}\text { Ezerlakósra } \\
\text { jutó } \\
\text { gépjármü }\end{array}$ \\
\hline \multirow{8}{*}{ 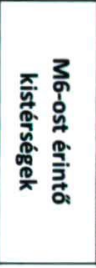 } & Moháesi & $-3,49$ & $-0,33$ & 1,46 & $-36,99$ & $-6,01$ & 557,04 & 5,99 & 10,71 & 60,56 & 75,99 & 43,49 & 6,12 \\
\hline & Pécsi & 1,04 & $-3,33$ & 3,14 & $-21,93$ & $-5,09$ & 369,58 & $-6,03$ & 9,50 & 14,23 & $-5,47$ & 18,97 & $-0,98$ \\
\hline & Pécs vámuli & $-4,07$ & 3,29 & 1,12 & $-31,56$ & $-7,53$ & 373,03 & $-11,51$ & 15,37 & 36,72 & $-19,75$ & 30,09 & 4,95 \\
\hline & Siklósi & $-3,05$ & $-10,90$ & 0,84 & $-24,30$ & $-4,54$ & 524,31 & 33,26 & 1,78 & 58,72 & $-28,89$ & 6,58 & 2,90 \\
\hline & Paksi & $-4,13$ & 10,58 & 0,80 & $-31,23$ & $-1,65$ & 586,53 & 4,60 & 12,49 & 60,26 & $-9,08$ & 10,60 & 8,30 \\
\hline & Szekszírdi & $-4,13$ & 0,50 & 0,97 & $-28,15$ & $-2,74$ & 380,25 & $-3,04$ & 4,74 & 33,01 & $-29,57$ & 21,08 & 4,21 \\
\hline & Bomyládi & $-4,31$ & 6,69 & 0,92 & $-29,20$ & $-3,26$ & 507,28 & $-4,57$ & 7,77 & 43,83 & $-52,22$ & 42,42 & 9,93 \\
\hline & Aflay: & $-3,16$ & 0,93 & 1,32 & $-29,05$ & $-4,40$ & 471.15 & 2,67 & 8,91 & 43,90 & $-9,86$ & 24,75 & 5,06 \\
\hline & & & & & & & & & & & & & \\
\hline \multirow{8}{*}{ 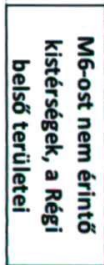 } & Sásdi & $-5,69$ & $-3,74$ & 0,53 & $-34,86$ & $-10,20$ & 277,16 & 0,00 & 8,70 & 50,15 & 53,60 & $-7,37$ & 8,61 \\
\hline & Szzigetvári & $-3,98$ & $-5,88$ & 1,01 & $-26,00$ & $-7,16$ & 465,73 & 5,84 & 14,05 & 81,62 & $-29,91$ & 53,97 & 5,00 \\
\hline & Dombóváni & $-4,21$ & 2,43 & 1,44 & $-23,53$ & $-4,96$ & 443,42 & $-2,83$ & 1,58 & 29,90 & $-40,93$ & $-6,56$ & 5,73 \\
\hline & Tamási & $-5,76$ & $-2,30$ & 0,42 & $-24,77$ & $-6,60$ & 453,11 & 4,31 & 6,34 & 77,29 & 1,15 & $-1,85$ & 8,84 \\
\hline & Bancsi & $-6,07$ & $-0,77$ & 0,18 & $-30,76$ & $-6,31$ & 529,28 & $-4,98$ & 3,81 & 85,70 & $-32,63$ & 29,96 & 7,66 \\
\hline & Tabi & $-17,43$ & $-1,94$ & $-11,69$ & 3,37 & $-17,42$ & 343,30 & $-20,59$ & $-7,10$ & 57,81 & 125,00 & $-14,63$ & 11,46 \\
\hline & Kaposvár & $-18,42$ & 2,96 & $-14,40$ & $-24,60$ & $-18,29$ & 239,79 & $-16,03$ & $-2,02$ & 14,53 & $-30,21$ & $-18,23$ & 7,39 \\
\hline & Athg: & $-8,79$ & $-1,32$ & -3.21 & $-23,02$ & $-10,13$ & 393,11 & $-4,90$ & 3,62 & 56,71 & 6,58 & 5,04 & 7,81 \\
\hline
\end{tabular}

Forrás: KSH Megyei Évkönyvei (2006-2010) adatai alapján saját szerkesztés, az adatok \%-ban vannak kifejezve 
A turisztikai mutatók egymással ellentmondóak, mert a kereskedelmi szálláshelyek száma 2006-2010 között az autópálya közelében lévỏ kistérségeknél csökkent átlagosan 9,86\%-kal a régió belső területein növekedett $6,58 \%$-kal, míg a magánszálláshelyek számánál mindkét vizsgált területe, de nem azonos mértékben az autópálya közelében átlagosan $24,75 \%$-ban, a belső területeken csak 5,04\%-ban.

A népesség számának a csökkenése az egész dél-dunántúli régiót sújtja, népesség fogyása az M6-os közelében kisebb mértékü átlagosan 3,16\%, mint az autópályától távolabb eső területeken $\mathbf{8 , 7 8 \%}$. Ugyanilyen tendenciát mutat a nyugdíjban, nyugdíjszerü ellátásban részesülök számának változása is 2006-2010 között.

A két vizsgált területegységnél a lakásállomány számának változásai is mutatja a regionális különbségeket. Az M6 közelében lévő kistérségeknél 2010-re átlagosan 1,32\%kall több lakás volt, mint 2006-ban, addig a Dél-Dunántúl belső területein csökkent a lakásállomány száma átlagosan 3,21\%-kal.

\section{3. ÖSSZEGZÉS ÉS JAVASLATOK}

Összegzésképen elmondható, hogy a kistérségekét csoportjánál (M6-os által érintett, belső nem érintett) merőben más gazdasági, szociális és ellátottsági mutatókkal jellemezhetők. Az M6-os autópályához közeli kistérségekben jobb az áru, a tőke és az emberek mobilitása. Az biztos, hogy regionális különbségeket nem lehet csak autópálya meglétével magyarázni, mert az autópályák jelentős hatást csak akkor fejtenek ki, ha határtólhatárig vezetnek, betöltve összekötő szerepüket, rajtuk használatarányos útdij szedés valósul meg, illetve olyan gazdaságilag prosperáló jelentős gazdasági potenciállal rendelkező környezetben épülnek, amely képes a helyi szolgáltatásokat erösíteni, új befektetőket vonzani, és az egész régióra nézve gazdaságélénkítő hatást kifejteni.

Az M6, illetve M60 gyorsforgalmi út jelenleg nem kapcsolódik egyetlen horvátországi határátkelőhöz sem, ezáltal a határtól-határig szakasz követelményét nem elégíti ki, csak Budapest elérhetöségét növeli.

A Régió gazdasági mutatói az ország bruttó hozzáadott érték termelésében más régiókkal összevetve a legalacsonyabb:

$\begin{array}{ll}- & \text { az ipar }(6 \%) \\ - & \text { az építöipar }(9 \%)\end{array}$

- $\quad$ a szolgáltatások $(6,2 \%)$ aránya és

előállítása.

a régió összes bruttó hozzáadott értékének (6,5\%)

Ilyen feltételrendszer mellett az M6-os autópályának csak gyenge regionális hatását lehet kimutatni. Az autópálya megépítése elött már a befektetök a telephelyüket az autópálya mentére tervezték, de két év üzemelés után nehéz regionális hatásokról beszélni. Ahhoz, hogy az autópálya kihasználtsága erősödjön, az egész Dél-dunántúli régió gazdasági potenciálját növelni kell (Egyházy Z. 2007). ${ }^{33}$ Fejleszteni szükséges a kombinált szállítás lehetőségeket, mert már erre biztosított a mohácsi, paksi és fadi kikötők. Horvátország Európai Unióhoz való csatlakozásával a határok átjárhatóbbá válnak, ezért az M6-os autópályát érdemes lenne összekötni a balkáni államok fö közlekedési útvonalaival, igy jobb elérhetőséget biztosítanánk a föbb gazdasági centrumok felé, és maga a régió fejlödését is elősegítenénk.

\section{FELHASZNÁLT IRODALOM}

Buday-Sántha A. (2011): Dél-Dunántúli régió kutatás, TÁMOP - 4.2.1.B - 10/2/KONV 2010-0002, Munkaváltozat, PTE KTK Regionális Politika és Gazdaságtan Doktori Iskola, Pécs.

\footnotetext{
${ }^{33}$ Térség gazdasága által megtermelt javak mennyisége és értéke az életszínvonallal párhuzamosan befolyásolta, befolyásolja a közlekedés fejlesztésének intenzitását.
} 
Egyházy Z. (2007): Magyarország közlekedési kapcsolatai az európai térségfejlesztésben és a regionális együttmüködésben, Budapesti Corvinus Egyetem,

Világgazdasági Tanszék, Nemzetközi Kapcsolatok Multidiszciplináris Doktori Iskola, Budapest.

Erdösi F. (2006): Transzeurópai közlekedési tengelyek fejlesztési iránya és hatása a balkán térszerkezetére, MTA Regionális Kutatások Központja, Pécs.

Kálnoki Müszaki és Gazdasági Tanácsadó Kft. (2003): A gyorsforgalmi úthálózat fejlesztésének gazdaságélénkítö hatása, Budapest.

Ormai Zs. (2005): A hazai autópálya-fejlesztések a transzeurópai közlekedési hálózatok tükrében, Budapest.

Központis Statisztikai Hivatal (2006-2010): Területi Statisztikai Évkönyvei, Központi Statisztikai Hivatal, Budapest. 